\title{
Editorial - mining in global history
}

Rather than being the product of a panel in a conference or workshop, the following cluster of three articles came about through a serendipitous conjuncture of submissions. This may reflect the fact that mining is a subject that lends itself easily to treatment by global historians, at least in the era of modern transport, as supplies of raw materials are often located capriciously far from processors, and from consumers of final products.

Chris Evans and Olivia Saunders demonstrate that there was quite an abrupt shift for the copper-smelting industry of Swansea (Abertawe) in South Wales in the 1830s. From handling relatively local Cornish and North Welsh ores, the Welsh port quickly moved to obtaining supplies from across the world, bolstered by abundant stocks of excellent coal, new smelting technologies, and British financial expertise. However, Swansea's position as the unrivalled workshop of the copper world lasted for only a few decades. Multiple nodes emerged across the globe in the aftermath of the American Civil War, reflecting further technological development and the erection of new trade barriers. This history of shifting patterns of global processing domination could profitably be extended to other commodities.

Ian Phimister moves the debate on to the provision of capital for what had become a highly globalized mining industry by the late nineteenth century. While the City of London could be an efficient provider of cheap funds for mining operations around the world, it could also become a centre for the market manipulation of share prices. In the case of the gold mines of what is now Zimbabwe, it was the latter phenomenon that prevailed, together with speculation in allied railway construction. At the same time, local dynamics of African rebellion starved potential mining developments of labour. This is a case study of how imperfect, and wilfully distorted, information could undermine apparent strides in globalization, and there are distinct parallels in the history of speculation in agricultural commodities, such as rubber.

Stephen Tuffnell focuses on yet another aspect of international mining, the role of highly skilled and very geographically mobile American mining engineers. These men not only spread around the world but they also brought with them, and developed, certain racial attitudes. In southern Africa, where they formed a distinct foreign 'colony', they imbibed new ideas about managing indigenous labourers. Those who had experienced conditions in southern Africa brought with them an alleged racial expertise in supervising mine workers in North America, Latin America, and beyond. Mining engineers, in turn, were but one segment of a wider set of global professional specialists, transcending imperial boundaries since Victorian times, which could be a fruitful area for new research.

With the exception of oil, mining has been somewhat eclipsed by agricultural products in the history of 'commodity chains', and this cluster of articles demonstrates how much potential there is in viewing the sector through the lens of global history. Mining corporations grew enormously in size and scope from the nineteenth century, mobilizing 
$2 \mid$ E D ITORIA L

labour (both skilled and unskilled), capital, shipping, and technology. They spread a marketing network for ores, semi-manufactures, smelted metals, and final consumer goods around the globe and much remains to be discovered about this process.

William G. Clarence-Smith 